\title{
Assembly Line Balancing Using Fuzzy Logic: A Case Study of a Tricycle Assembly Line
}

\author{
Anthony I. Unuigbe1 ${ }^{*}$, Henry A. Unuigbe², Eddy O. Aigboje1, Polycarp A. Ehizibue1 \\ ${ }^{1}$ Department of Industrial and Production Engineering, Ambrose Alli University, Ekpoma, Nigeria \\ ${ }^{2}$ Lloyd's Register EMEA (Nigeria) Ltd., Apapa, Nigeria

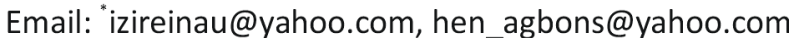

Received 20 April 2016; accepted 12 June 2016; published 15 June 2016

Copyright (C) 2016 by authors and Scientific Research Publishing Inc.

This work is licensed under the Creative Commons Attribution International License (CC BY).

http://creativecommons.org/licenses/by/4.0/

(c) (i) Open Access

\begin{abstract}
The application of fuzzy logic in balancing a single model tricycle assembly line is presented in this study. MATLAB simulation software was used in the analysis of the primary and secondary data obtained from the assembly line under study. Results obtained from the study show that the efficiency of the line increased from $88.1 \%$ to $92.4 \%$. The total idle time was also reduced by $56.5 \%$. This indicates an improvement in the efficiency of the line, reduction of bottleneck, and even distribution of tasks along the line for the company under study.
\end{abstract}

\section{Keywords}

\section{Line Balancing, Fuzzy Logic, Efficiency, Idle Time}

\section{Introduction}

The manufacturing Assembly Line was first introduced by Henry Ford in the early 1900's. It was designed to be an efficient and highly productive way of manufacturing a particular product. The basic assembly line consists of a set of work stations arranged in a linear version with each station connected by a material handling device. The basic movement of material through an assembly line begins with a part being fed into the first station at a predetermined feed rate. A station is considered at any point on the assembly line in which a task is performed on the part. These parts can be performed by machinery, robots and/or human workers. Once the part enters a station, a task is then performed on the part, and the part is fed to the next operation. The time it takes to complete a task at each operation is known as the process time [1].

One of the main issues concerning the development of an Assembly Line is how to arrange the task to be performed. This arrangement may be some times subjective but has to be dictated by implied rules, set forth by

*Corresponding author.

How to cite this paper: Unuigbe, A.I., Unuigbe, H.A., Aigboje, E.O. and Ehizibue, P.A. (2016) Assembly Line Balancing Using Fuzzy Logic: A Case Study of a Tricycle Assembly Line. Open Journal of Optimization, 5, 59-70. 
the production sequence. For the manufacturing of any item, there are some sequences of task that must be followed. Line balancing is a tool that can be used to optimize the workstation or assembly line throughput. This tool assists in the reduction of the production time and maximizing the output or minimizing the cost. Assembly line is a flow oriented production system where the productive units performing the operation referred to the workstation and the work pieces move from one station to another with some kind of transportation system. In an assembly line, bottlenecks will create a queue and a longer overall cycle time.

Helgeson et al. [2] were the first to propose the assembly line balancing problem (ALBP) and [3] was the first to publish the problem in its mathematical form. However, during the first forty years of the Assembly Line existence, only trial and errors were used to balance the line [4]. Since then, there have been numerous methods developed to solve the different forms of the ALBP. Salveson [3] provided the first mathematical attempt by solving linear program. Gutjahr and Nemhauser [5] also showed that the ALBP problem falls into the class of Non deterministic polynomial (NP) - hard combinatorial optimization problems. This means that the optimal solution is not guaranteed for problems of significant size. Since then, many methods for solving assembly ALBP has been developed by researchers.

Gamberini et al. [6] presented their work on a new multi-objective heuristic algorithm for solving the stochastic assembly line re-balancing problem. They were able to solve stochastic task variation problem and optimize the production line. Peeter and Degraeve [7] worked on linear programming based lower bound for the simple assembly line balancing problem. They were able to generate an algorithm that solved the pricing problem.

Toksari, et al. [8] worked on assembly line balancing problem with deterioration of tasks and learning effects. The study led to an increase in the rate of production. Fan, et al. [9] worked on balancing and simulating of assembly line with overlapped and stopped operation, under certain and uncertain environments. They were able to optimize workstations.

Otto and Scholl [10] worked on discrete optimization incorporating ergonomic risks into assembly line balancing. They were able to reduce line balancing causes and relocate the workforce associated with idle time. Eliminating bottle neck, and at the same time improving productivity. Strategic robust mixed model assembly line balancing based on scenario planning was studied by Weida and Tianyuan [11]. A robust model based on worst case scenario was developed to garment factories and experimental designs were used to evaluate GGA's performance. They were able to optimize and increase performance of the assembly line.

Manavizadeh et al. [12] applied mixed-model assembly line balancing in the make-to-order and stochastic environment using multi-objective evolutionary algorithms. They resulted in optimizing cycle time and the number of stations. Chutima and Chimklai [13] worked on multi-objective two-sided mixed-model assembly line balancing using particle swarm optimization with negative knowledge. They were able to minimize the cycle time, minimize total cost, and the smoothness index. Bdolreza et al. [14] presented a simulated annealing algorithm for multi-manned assembly line balancing problem. In this work, a simulated annealing heuristic was proposed for solving assembly line balancing problems with multi-manned workstations. Their work resulted in minimizing workstations and increasing productivity.

Ozbakir and Tapkan [15] worked on bee colony intelligence in zone constrained two sided assembly line balancing problem. At the end of the application of bee algorithm, they were able to minimize the number of work stations and the given cycle time. Chen, et al. [16] applied assembly line balancing in garment industry. A group genetic algorithm (GGA) was developed for assembly line balancing problem of sewing lines with different labour skill levels. The study resulted in the minimization of work stations.

Micieta, et al. [17] presented assembly line balancing algorithm with focus on new research in Ant colony optimization (ACO) approach. The procedure minimized the number of stations of the line as a major goal and considers the additional goal of smoothening the workload between and within workstations. Akpinar, et al. [18] adopted hybridizing ant colony optimization via genetic algorithm for mixed-model assembly line balancing problem, with sequence dependent setup times between tasks. It resulted in the reduction of idle time and minimization of workstations. Siddesh, et al. [19] adopted the line of balancing scheduling technique (LOBST) aimed at improving the line of balancing concepts on building construction and proved its usefulness. This method adopted, resulted in the optimization and minimization of work stations.

Hop [20] applied heuristic solution for fuzzy mixed-model line balancing problem. This work addressed the mixed-model line balancing problem with fuzzy processing time. Promising results were obtained and cycle time was minimized. Locally little or no work has been done on the use of line balancing in the industries. Therefore this study applies the use of fuzzy logic method as a safe and reliable technique for solving ALBP. In 
the implementation of the fuzzy method, the physical work load of a task is considered as a Fuzzy concept and a Fuzzy linear programming model is proposed.

\section{Methodology}

This research is based on data recorded at the Boulos Company Factory in Ogba Industrial Estate, Lagos, Nigeria. The secondary and primary data for this study was collected by recording actual times of tasks performed at each work station, and open interviews with the management and line workers.

\subsection{The Boulos Company Assembly Line}

The company assembly line consists of 8 work stations, 36 tasks and 31 workers. In order to carry out the time studies, an excel program was used to make time stamps at different stages of work at the assembly stations. Every product goes through an average of 7 - 8 stations before it leaves the assembly line.

\subsection{Line Balancing Losses}

The line balancing loss is calculated with the formula below:

$$
\text { Balancing Loss }(\%)=\frac{\text { Cycle Time }- \text { Processing Time }}{\text { Cycle Time }} \times 100 \%
$$

\section{Results and Discussion}

\subsection{Balancing the Existing Line}

Table 1 shows the time study for station 1 (Rear Arms Workstation).

Table 2 shows a sample of the time study for station 2 (Front Suspension Workstation).

Table 3 shows a sample of the time study for station 3 (Engine Unpacking Workstation).

Table 4 shows a sample of the time study for station 4 (Engine Preparation Workstation).

Table 5 shows a sample of the time study for station 5 (Brake Bleeding).

Table 6 shows a sample of the time study for station 6 (Engine Decking).

Table 7 shows a sample of the time study for station 7 (Cable Fitment).

Table 8 shows a sample of the time study for station 8 (Inspection).

Table 1. Time study for station 1.

\begin{tabular}{ccc}
\hline & \multicolumn{2}{c}{ WORKSTATION 1: REAR ARMS } \\
\hline TASK DESCRIPTION & TASK CODE & PROCESSING TIME IN SECONDS \\
\hline CHASSIS PREPARATION & C4 & 178.5 \\
REAR SUSPENSION FITMENT & B1 & 117.7 \\
BRAKE HOSE FITMENT & B2 & 100.4 \\
SHOCK ABSORBER & B3 & 71.5 \\
HAND BRAKE CABLE FITMENT & B4 & 123 \\
HAND BRAKE DRUM FITMENT & B5 & 38.5 \\
& TOTAL & 629.6 \\
& CYCLE TIME & 576 \\
& WORKERS & 6 \\
& BALANCING LOSS & $-9.3 \%$ \\
& UTILIZATION & $90.7 \%$ \\
\hline
\end{tabular}


Table 2. Time study for station 2.

\begin{tabular}{|c|c|c|}
\hline & \multicolumn{2}{|c|}{ WORKSTATION 2: FRONT SUSPENSION } \\
\hline TASK DESCRIPTION & TASK CODE & PROCESSING TIME IN SECONDS \\
\hline REPOSITIONING OF CHASSIS & $\mathrm{C} 1$ & 162.7 \\
\hline PACKAGING BACK FRAME & $\mathrm{C} 2$ & 190.4 \\
\hline HEAD LAMP FITMENT LHS & E3 & 66.6 \\
\hline HEAD LAMP FITMENT RHS & E4 & 64.3 \\
\hline HEAD LAMP FITMENT-3 & E5 & 90.1 \\
\hline FRONT SUSPENSION-1 & D1 & 272.8 \\
\hline FRONT SUSPENSION-2 & D2 & 121.7 \\
\hline FRONT BRAKE HOSE CONNECTION & C5 & 81.8 \\
\hline REAR TYRE FITMENT & D3 & 219.7 \\
\hline HORN & $\mathrm{F} 1$ & 23.7 \\
\hline \multirow[t]{7}{*}{ HANDLE BAR } & D4 & 67.2 \\
\hline & TOTAL & 1361 \\
\hline & CYCLE TIME & 576 \\
\hline & WORKERS & 6 \\
\hline & BALANCING LOSS & $-136.2 \%$ \\
\hline & UTILIZATION & $-36.2 \%$ \\
\hline & IDLE TIME & -785 \\
\hline
\end{tabular}

Table 3. Time study for station 3.

\begin{tabular}{ccc}
\hline & \multicolumn{2}{c}{ WORKSTATION 3: ENGINE UNPACKING } \\
\hline TASK DESCRIPTION & TASK CODE & PROCESSING TIME IN SECONDS \\
\hline ENGINE UNPACKING & A1 & 29 \\
\hline TOTAL & 29 \\
CYCLE TIME & 576 \\
WALANCING LOSS & 2 \\
BTILIZATION & $95 \%$ \\
IDLE TIME & $5 \%$ \\
\hline
\end{tabular}

Tables 1-8 are samples of primary data obtained for operations of workers at various stations on the tricycle assembly line. "Time taken to enter the station" is the time, in which an engine/chassis starts to move into the station. After it reaches the station and stops, the workers starts working immediately and finishes the job at the time "Worker stops working". Afterwards, at the time "Product Leaves", the product starts to move out of the station and at time "End of conveyor" it leaves the station fully. In some cases the cycle time increases dramatically and this was caused by fatigue, bottleneck or error in material handling. 
Table 4. Time study for station 4.

\begin{tabular}{ccc}
\hline & \multicolumn{2}{c}{ WORKSTATION 4: ENGINE PREPARATION } \\
\hline TASK DESCRIPTION & TASK CODE & PROCESSING TIME IN SECONDS \\
\hline EXHAUST/MUFFLER FITMENT & A2 & 135.5 \\
DRIVE SHAFT FITMENT & A3 & 111.5 \\
AIR BOX FITMENT & A4 & 77.7 \\
FRONT CROSS MEMBER & A5 & 67.1 \\
GEAR OIL & C3 & 45.3 \\
& TOTAL & 437.1 \\
& CYCLE TIME & 576 \\
& WORKERS & 4 \\
& BALANCING LOSS & $24.1 \%$ \\
\hline
\end{tabular}

Table 5. Time study for station 5.

\begin{tabular}{ccc|}
\hline & \multicolumn{2}{c|}{ WORKSTATION 5: BRAKE BLEEDING } \\
\hline TASK DESCRIPTION & TASK CODE & PROCESSING TIME IN SECONDS \\
\hline BRAKE FLUID TOPPING \& BLEEDING 1 & D5 & 114.7 \\
BRAKE FLUID TOPPING \& BLEEDING 2 & E1 & 139.5 \\
BRAKE FLUID TOPPING \& BLEEDING 3 & E2 & 127.1 \\
& TOTAL & 381.3 \\
& CYCLE TIME & 576 \\
& WORKERS & 3 \\
& BALANCING LOSS & $33.9 \%$ \\
& UTILIZATION & $66.1 \%$ \\
\hline
\end{tabular}

Table 6. Time study for station 6 .

\begin{tabular}{ccc}
\hline & \multicolumn{2}{c}{ WORKSTATION 6: ENGINE DECKING } \\
\hline TASK DESCRIPTION & TASK CODE & PROCESSING TIME IN SECONDS \\
\hline ENGINE CHASSIS FEEDING & F2 & 58 \\
REAR ARM TO FRAME & F3 & 99.1 \\
DRIVE SHAFT FITMENT & F4 & 125 \\
& TOTAL & 282.1 \\
CYCLE TIME & 576 \\
WORKERS & 2 \\
\hline
\end{tabular}


Table 7. Time study for station 7.

\begin{tabular}{ccc}
\hline & \multicolumn{2}{c}{ WORKSTATION 7: CABLE FITMENT } \\
\hline TASK DESCRIPTION & TASK CODE & PROCESSING TIME IN SECONDS \\
\hline CONTROL CABLE FITMENT 1 & F5 & 179.7 \\
CONTROL CABLE FITMENT 2 & G1 & 152.5 \\
FUEL HOSE FITMENT & G2 & 273.7 \\
& TOTAL & 605.9 \\
& CYCLE TIME & 576 \\
& WORKERS & 3 \\
\hline
\end{tabular}

Table 8. Time study for station 8 .

\begin{tabular}{ccc|}
\hline & & WORKSTATION 8: INSPECTION \\
\hline TASK DESCRIPTION & TASK CODE & PROCESSING TIME IN SECONDS \\
\hline END OF LINE INSPECTION & G3 & 13.9 \\
ROLLING ROD & G4 & 162.8 \\
EMISSION ANALYSIS & G5 & 37.9 \\
CO \& OIL TEMPERATURE & H1 & 119.3 \\
& TOTAL & 333.9 \\
CYCLE TIME & 576 \\
& WORKERS & 5 \\
BALANCING LOSS & $42 \%$ \\
UTILIZATION & $58 \%$ \\
\hline IDLE TIME & 242.1 \\
\hline
\end{tabular}

\subsection{Rebalancing and Optimization Using Fuzzy Logic (Figure 1)}

The MATLAB Fuzzy Logic Toolbox for optimization was used for the study.

\subsubsection{Defining the Inputs and Output Variables}

Inputs variables were defined as follows;

1) Total Processing Time.

2) Workers (within the range of 0 - 6).

3) Cycle Time.

4) Workstations (within the range of 0 - 10).

The Output variable was defined as utilization.

\subsubsection{Creating Membership Functions}

In this research, we used three sets of membership functions as shown in Table 9.

\subsubsection{Creating Rules}

The rules were created with the aim of allocating workers to stations in the best compromise in order to improve the efficiency of the station. 


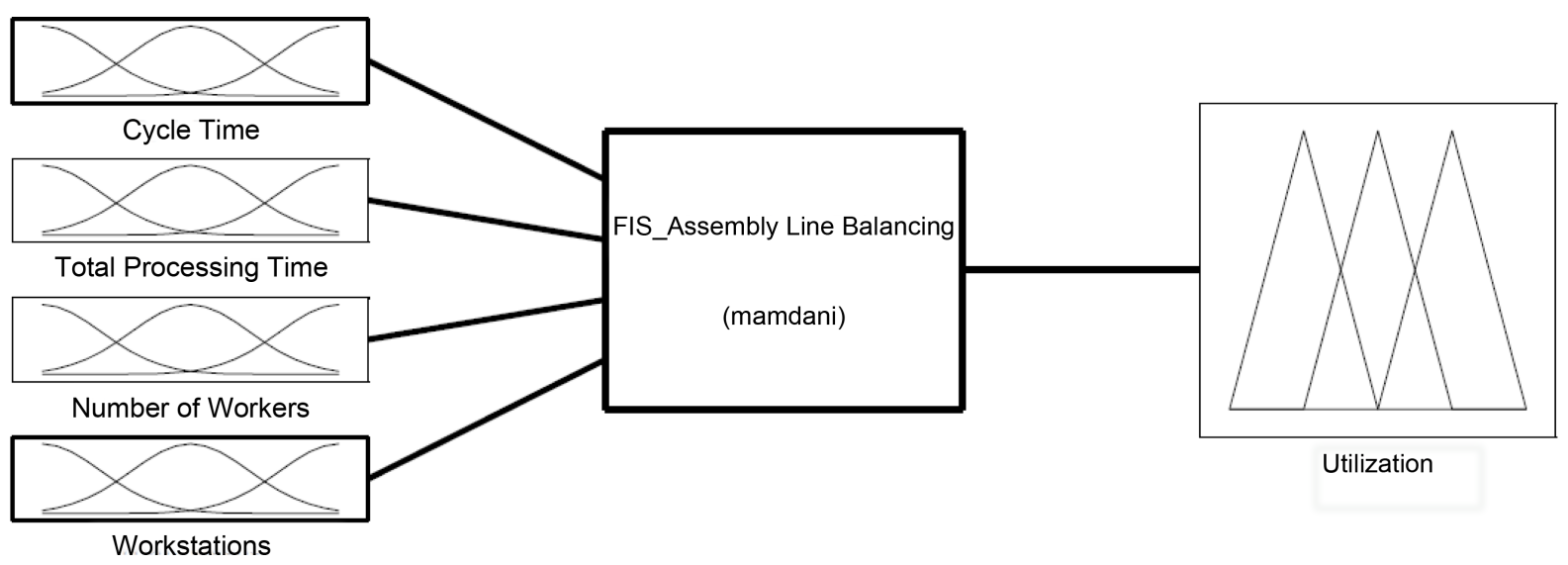

Figure 1. Fuzzy model block diagram for assembly line re-balancing.

Table 9. Membership functions for fuzzy logic.

\begin{tabular}{cccc}
\hline Variables & $\begin{array}{c}\text { Gausmf }(0-1), \\
\text { Parameters }\end{array}$ & $\begin{array}{c}\text { Trapmf }(0-1) \\
\text { Parameters }\end{array}$ & $\begin{array}{c}\text { Trimf }(0-1) \\
\text { Parameters }\end{array}$ \\
\hline Total Processing Time & {$[223637265216]$} & {$[2527343640164925]$} & {$[223637265216]$} \\
Cycle Time & {$[97.76576]$} & {$[390.6531 .2620 .8761 .4]$} & {$[345.8576806 .2]$} \\
Number of Workers & {$[26]$} & {$[1.7615 .5296 .47110 .24]$} & {$[1.29610 .71]$} \\
Workstation 1 & {$[91.3537 .6]$} & {$[344.1516 .1559 .1731 .1]$} & {$[322.6537 .6752 .6]$} \\
Workstation 2 & {$[94.78558 .1]$} & {$[357.2535 .8580 .4759]$} & {$[334.9558 .1781 .3]$} \\
Workstation 3 & {$[89.31525 .8]$} & {$[336.5504 .8546 .8715 .1]$} & {$[315.5525 .8736 .1]$} \\
Workstation 4 & {$[95.53562 .4]$} & {$[381.3518 .5606 .3743 .5]$} & {$[337.4562 .4787 .4]$} \\
Workstation 5 & {$[95.29561]$} & {$[359538.6583 .4763]$} & {$[336.6561785 .4]$} \\
Workstation 6 & {$[94.25554 .9]$} & {$[376.2511 .6598 .2733 .6]$} & {$[332.9554 .9776 .9]$} \\
Workstation 7 & {$[72.44426 .2]$} & {$[272.8409 .1443 .3579 .7]$} & {$[255.7426 .2596 .7]$} \\
Workstation 8 & {$[56.75333 .9]$} & {$[226.3307 .8360441 .5]$} & {$[200.2333 .9467 .6]$} \\
\hline
\end{tabular}

- If processing time is low, or worker is less, then station utilization is minimum

- If processing time is average, then station utilization is moderate

- If processing time is high, or worker is more, then station is maximum

In order to illustrate the applicability of the proposed simulation model, the assembly line was rebalanced and the best compromise solution is shown in Tables 10-16.

Tasks were evenly distributed during rebalancing. Precedence constraints were followed and each workstation total processing time was below the cycle time. In order to evaluate the performance of the proposed model, sets of problems were used from the rebalanced assembly line. For each problem, the number of workstation processing time and the number of workers was evaluated, and each task in a workstation can be processed by any worker. The assembly line was rebalanced, while a statistical dependence was maintained: Statistical dependence of task times on the task type.

\section{Discussion}

It is observed that the main problems with the line balancing and the reasons for balancing losses are the absence of standardized work, work time deviations between workers, deviations between work content provided by the company used as case study and the ones workers follow, non value adding operations like long transportation between stations, lack of information about the performance of the stations. To be able to deal with these problems, 
Table 10. Rebalanced workstation 1 processing time, cycle time, balancing loss and utilization.

\begin{tabular}{ccc|}
\hline & \multicolumn{2}{c|}{ WORKSTATION 1: ENGINE PREPARATION } \\
\hline TASK DESCRIPTION & TASK CODE & PROCESSING TIME IN SECONDS \\
\hline EXHAUST/MUFFLER FITMENT & A2 & 135.5 \\
ENGINE UNPACKING & A1 & 29 \\
SHOCK ABSORBER & B3 & 71.5 \\
DRIVE SHAFT FITMENT & A3 & 111.5 \\
AIR BOX FITMENT & A4 & 77.7 \\
FRONT CROSS MEMBER & A5 & 67.1 \\
GEAR OIL & C3 & 45.3 \\
& TOTAL & 537.6 \\
& CYCLE TIME & 576 \\
& WORKERS & 4 \\
& BALANCING LOSS & $6.70 \%$ \\
& UTILIZATION & $93.30 \%$ \\
\hline
\end{tabular}

Table 11. Rebalanced workstation 2 processing time, cycle time, balancing loss and utilization.

\begin{tabular}{ccc}
\hline & \multicolumn{2}{c}{ WORK STATION 2: REAR ARMS } \\
\hline TASK DESCRIPTION & TASK CODE & PROCESSING TIME IN SECONDS \\
\hline CHASSIS PREPARATION & C4 & 178.5 \\
REAR SUSPENSION FITMENT & B1 & 117.7 \\
BRAKE HOSE FITMENT & B2 & 100.4 \\
HAND BRAKE CABLE FITMENT & B4 & 123 \\
HAND BRAKE DRUM FITMENT & B5 & 38.5 \\
& TOTAL & 558.1 \\
& CYCLE TIME & 576 \\
& WORKERS & 4 \\
& BALANCING LOSS & $3.10 \%$ \\
& UTILIZATION & $96.90 \%$ \\
\hline
\end{tabular}

information about the stations were made available in order to rebalance, in line with the existing situation.

\subsection{Line Efficiency}

Line efficiency before rebalancing was calculated,

$$
\begin{aligned}
& \text { Efficiency }(\%)=\frac{\text { Total Sum of Processing time }}{\text { Total Number of Workstations } \times \text { Cycle Time }} \times 100 \\
& \text { Efficiency }(\%)=\frac{4059.9}{8 \times 576} \times 100 \\
& \text { Efficiency }(\%)=\frac{405.99}{4608}
\end{aligned}
$$


Table 12. Rebalanced workstation 3 processing time, cycle time, balancing loss and utilization.

\begin{tabular}{ccc}
\hline & \multicolumn{2}{c}{ WORK STATION 3: FRONT SUSPENSION } \\
\hline TASK DESCRIPTION & TASK CODE & PROCESSING TIME IN SECONDS \\
\hline REPOSITIONING OF CHASSIS & C1 & 162.7 \\
PACKAGING BACK FRAME & C2 & 190.4 \\
FRONT BRAKE HOSE CONNECTION & C5 & 81.8 \\
HORN & F1 & 23.7 \\
HANDLE BAR & D4 & 67.2 \\
& TOTAL & 525.8 \\
& CYCLE TIME & 576 \\
& WORKERS & 4 \\
& BALANCING LOSS & $8.70 \%$ \\
UTILIZATION & $91.30 \%$ \\
\hline
\end{tabular}

Table 13. Rebalanced workstation 4 processing time, cycle time, balancing loss and utilization.

\begin{tabular}{ccc}
\hline & \multicolumn{2}{c}{ WORK STATION 4: FRONT SUSPENSION 2 } \\
\hline TASK DESCRIPTION & TASK CODE & PROCESSING TIME IN SECONDS \\
\hline HEAD LAMP FITMENT LHS & E3 & 66.6 \\
HEAD LAMP FITMENT RHS & E4 & 64.3 \\
HEAD LAMP FITMENT-3 & E5 & 90.1 \\
FRONT SUSPENSION-2 & D2 & 121.7 \\
REAR TYRE FITMENT & D3 & 219.7 \\
& TOTAL & 562.4 \\
& CYCLE TIME & 576 \\
& WORKERS & 2 \\
& BALANCING LOSS & $2.40 \%$ \\
& UTILIZATION & $97.60 \%$ \\
\hline
\end{tabular}

Table 14. Rebalanced workstation 5 processing time, cycle time, balancing loss and utilization.

\begin{tabular}{ccc}
\hline & \multicolumn{2}{c|}{ WORK STATION 5: BRAKE BLEEDING } \\
\hline TASK DESCRIPTION & TASK CODE & PROCESSING TIME IN SECONDS \\
\hline BRAKE FLUID TOPPING \& BLEEDING 1 & D5 & 114.7 \\
BRAKE FLUID TOPPING \& BLEEDING 2 & E1 & 139.5 \\
BRAKE FLUID TOPPING \& BLEEDING 3 & E2 & 127.1 \\
CONTROL CABLE FITMENT 1 & F5 & 179.7 \\
& TOTAL & 561 \\
& CYCLE TIME & 576 \\
& WORKERS & 3 \\
& BLANCING LOSS & $2.60 \%$ \\
\hline
\end{tabular}


Table 15. Rebalanced workstation 6 processing time, cycle time, balancing loss and utilization.

\begin{tabular}{ccc}
\hline & \multicolumn{2}{c}{ WORK STATION 6: ENGINE DECKING } \\
\hline TASK DESCRIPTION & TASK CODE & PROCESSING TIME IN SECONDS \\
\hline ENGINE CHASSIS FEEDING & F2 & 58 \\
REAR ARM TO FRAME & F3 & 99.1 \\
DRIVE SHAFT FITMENT & F4 & 125 \\
FRONT SUSPENSION-1 & D1 & 272.8 \\
& TOTAL & 554.9 \\
& CYCLE TIME & 576 \\
& WORKERS & 2 \\
& BALANCING LOSS & $5.40 \%$ \\
& UTILIZATION & $94.60 \%$ \\
\hline
\end{tabular}

Table 16. Rebalanced workstation 7 processing time, cycle time, balancing loss and utilization.

\begin{tabular}{ccc}
\hline & \multicolumn{2}{c}{ WORK STATION 7: CABLE FITMENT } \\
\hline TASK DESCRIPTION & TASK CODE & PROCESSING TIME IN SECONDS \\
\hline CONTROL CABLE FITMENT 2 & G1 & 152.5 \\
FUEL HOSE FITMENT & G2 & 273.7 \\
TOTAL & 426.2 \\
CYCLE TIME & 576 \\
WORKERS & 2 \\
BALANCING LOSS & $26 \%$ \\
UTILIZATION & $74 \%$ \\
IDLE TIME & 149.8 \\
\hline
\end{tabular}

Test carried out using MATLAB Fuzzy Inference System, gave efficiency result in Triangular Fuzzy Numbers TFN.

$$
\begin{aligned}
& \operatorname{Efficiency}(\%)=\frac{3726}{7 \times 576} \times 100 \\
& \operatorname{Efficiency}(\%)=\frac{372600}{4032}=92.4 \%
\end{aligned}
$$

Test carried out using Matlab Fuzzy Inference System, gave efficiency result in Triangular Fuzzy Numbers TFN.

\subsection{Idle Time}

Total idle time before rebalancing was calculated;

$$
\begin{aligned}
& \text { Total Idle Time }(\%)=\frac{\text { Total Sum of Workstations Idle Time } \times 100}{\text { Total Number of Workstations } \times \text { Cycle Time }} \\
& \text { Total Idle Time }(\%)=\frac{54740}{4608}=11.88 \%
\end{aligned}
$$


Total idle time after rebalancing was calculated;

$$
\text { Total Idle Time }(\%)=\frac{30600}{4032}=7.59 \%
$$

In this research there was a change in total efficiency and idle time between the initial data and the actual data. Change in workstations processing time, balancing loss, number of workers and utilization occurred after rebalancing and was optimized using MATLAB fuzzy logic tool box.

\section{Conclusion}

This study is based on the application of fuzzy logic on a single model assembly line. The secondary data received from the company used as case study had a cycle time of 576 seconds, number of workstations being 8 and the total processing time of 4099.9 seconds, while primary data obtained has similar cycle time, number of workstations and varying total processing time of 4059.9 seconds. Rebalancing the assembly line was necessary, for the validation of the proposed model (fuzzy logic toolbox). The result of the initial efficiency in triangular fuzzy number was $(58.7,73.4,88.1)$ and idle time was (11.88\%), giving a range of $58.7 \%-88.1 \%$ and the actual efficiency from the performance of the model in triangular fuzzy number was $(61.6,77,92.4)$ and idle time was (7.59\%), giving a range of $61.6 \%-92.4 \%$, which was an improvement compared to the initial result. The performance of the developed model was validated through numerical experiments, the result indicated that the proposed approach improved quality of solution and enhanced the rate of convergence than other existing approaches.

\section{Acknowledgements}

The authors are grateful to Peace Amilegbe, Blessing Ehebhamen and Clementina Ekhareafo (Industrial and Production Engineering Department, Ambrose Alli University, Ekpoma, Nigeria) for participation in the primary data collection. The authors would also like to thank Mr. Julian Hady and Mr. Olusegun Adekoya ( Boulous Enterprises Limited, Lagos, Nigeria) for provision of relevant information and secondary data.

\section{References}

[1] Fonseca, D.J., Guest, C.L., Elam, M. and Karr, C.L. (2005) A Fuzzy Logic Approach to Assembly Line Balancing. Mathware \& Soft Computing, 12, 57-74.

[2] Helgeson, W.B. and Birnie, D.P. (1961) Assembly Line Balancing Using the Ranked Positional Weighting Technique. Journal of Industrial Engineering, 12, 394-398.

[3] Salveson, M.E. (1955) The Assembly Line Balancing Problem. Journal of Industrial Engineering, 6, 18-25.

[4] Erel, E. and Sarin, S.C. (1998) A Survey of the Assembly Line Balancing Procedures. Production Planning and Control, 9, 414-434. http://dx.doi.org/10.1080/095372898233902

[5] Gutjahr, A.L. and Neumhauser, G.L. (1964) An Algorithm for the Balancing Problem. Management Science, 11, 308315. http://dx.doi.org/10.1287/mnsc.11.2.308

[6] Gamberini, R., Grassi, A. and Rimini, B. (2006) A New Multi-Objective Heuristic Algorithm for Solving the Stochastic Assembly Line Re-Balancing Problem. International Journal of Production Economics, 102, 226-243. http://dx.doi.org/10.1016/j.ijpe.2005.02.013

[7] Peeters, M. and Degraeve, Z. (2006) A Linear Programming Based Lower Bound for the Simple Assembly Line Balancing Problem. European Journal of Operational Research, 168, 716-731. http://dx.doi.org/10.1016/j.ejor.2004.07.024

[8] Toksari, D.V., Isleyen, S.K., Guner, E. and Baykoc, O.F. (2008) Simple and U-Type Assembly Line Balancing Problems with a Learning Effect. Applied Mathematical Modelling, 32, 2954-2961. http://dx.doi.org/10.1016/j.apm.2007.10.007

[9] Fan W., Gao, Z., Xu, W. and Xiao, T. (2010) Balancing and Simulating of Assembly Line with Overlapped and Stopped Operation. Simulation Modelling Practice and Theory, 18, 1069-1079. http://dx.doi.org/10.1016/j.simpat.2009.11.008

[10] Otto, A. and Scholl, A. (2011) Incorporating Ergonomic Risks into Assembly Line Balancing. European Journal of Operational Research, 212, 277-286. http://dx.doi.org/10.1016/j.ejor.2011.01.056 
[11] Xu, W.D. and Xiao, T.Y. (2011) Strategic Robust Mixed Model Assembly Line Balancing Based on Scenario Planning. Tsinghua Science and Technology, 16, 308-314. http://dx.doi.org/10.1016/S1007-0214(11)70045-1

[12] Manavizadeh, N., Rabbani, M., Moshtaghi, D. and Jolai, M. (2012) Mixed-Model Assembly Line Balancing in the Make-to-Order and Stochastic Environment Using Multi-Objective Evolutionary Algorithms. Expert Systems with Applications, 39, 12026-12031. http://dx.doi.org/10.1016/j.eswa.2012.03.044

[13] Chutima, P. and Chimklai, P. (2012) Multiobjective Two-Sided Mixed-Model Assembly Line Balancing Using Particle Swarm Optimisation with Negative Knowledge. Computers \& Industrial Engineering, 62, 39-55. http://dx.doi.org/10.1016/j.cie.2011.08.015

[14] Roshania, R., Roshani, A., Roshani, A., Salehi, M. and Esfandyari, A (2013) A Simulated Annealing Algorithm for Multi-Manned Assembly Line Balancing Problem. Journal of Manufacturing Systems, 32, 238-247. http://dx.doi.org/10.1016/j.jmsy.2012.11.003

[15] Ozbakir, L. and Tapkan, P. (2011) Bee Colony Intelligence in Zone Constrained Two-Sided Assembly Line Balancing Problem. Expert Systems with Applications, 38, 11947-11957. http://dx.doi.org/10.1016/j.eswa.2011.03.089

[16] Chen, J.C., Chen, C.C., Su, L.H., Wu, H.B. and Sun, C.-H. (2012) Assembly Line Balancing in Garment Industry. Expert Systems with Applications, 39, 10073-10081. http://dx.doi.org/10.1016/j.eswa.2012.02.055

[17] Micieta, B. and Stollmann, V. (2011) Assembly Line Balancing. DAAM International Scientific Book (Chapter 21), 257-264. http://dx.doi.org/10.2507/daaam.scibook.2011.21

[18] Akpınara, S., Bayhan, G.M. and Baykasoglu, A. (2013) Hybridizing Ant Colony Optimization via Genetic Algorithm for Mixed-Model Assembly Line Balancing Problem with Sequence Dependent Setup Times between Tasks. Applied Soft Computing, 13, 574-589. http://dx.doi.org/10.1016/j.asoc.2012.07.024

[19] Siddesh, K.P., Preeti, V. and Shweta, R. (2013) Application of Line of Balance Scheduling Technique (LOBST) for a Real estate sector. International Journal of Science, Engineering and Technology Research (IJSETR), 2, 82-94.

[20] Hop, V.N. (2006) A Heuristic Solution for Fuzzy Mixed-Model Line Balancing Problem. European Journal of Operational Research, 168, 798-810. http://dx.doi.org/10.1016/j.ejor.2004.07.029

\section{Submit or recommend next manuscript to SCIRP and we will provide best service for you:}

Accepting pre-submission inquiries through Email, Facebook, Linkedin, Twitter, etc

A wide selection of journals (inclusive of 9 subjects, more than 200 journals)

Providing a 24-hour high-quality service

User-friendly online submission system

Fair and swift peer-review system

Efficient typesetting and proofreading procedure

Display of the result of downloads and visits, as well as the number of cited articles

Maximum dissemination of your research work

Submit your manuscript at: http://papersubmission.scirp.org/ 